\title{
VERTICAL RESTRAINTS FACILITATING HORIZONTAL COLLUSION: 'STRETCHING' AGREEMENTS IN A COMPARATIVE APPROACH
}

\author{
Murilo Lubambo*
}

\begin{abstract}
This article discusses the approaches of the European Union (EU) and of the United States (US) to the notions of agreement and concerted practice applied to horizontal collusive consequences of vertical restraints. It concludes that networks of vertical restraints blur the differences between vertical and horizontal agreements; therefore, both options of attack are available for enforcers in the EU and the US context. If the analysed vertical restraints are adopted in parallel by agreement, they should be deemed illegal as long as they restrict competition producing collusive consequences. In the absence of explicit coordination to adopt the practice, I suggest first looking for a stretched concept of horizontal agreement or a broadly interpreted concept of concerted practice, including unilateral 'communication' that intentionally reduces uncertainty. Even when the analysed practices are adopted individually and not by all firms, they can represent a commitment to focal points, observable by market players, thus amounting to communication of intent. If that is not possible, I propose that an analysis of market power, incentives, coercion and induction should guide the finding of an illegal vertical agreement and ground the analysis of the consequences. The agreement/concerted practice path is an appropriate, feasible and coherent way to deal with vertical restraints facilitating horizontal tacit coordination, but that does not exclude alternative effective enforcement mechanisms.
\end{abstract}

\section{A. INTRODUCTION}

This article discusses the approaches of the European Union (EU) and of the United States (US) to the notions of agreement and concerted practice applied to horizontal collusive consequences of vertical restraints. In order to avoid misunderstandings, I shall use 'collusion' to label the 'economic' notion of supra-competitive outcomes in some oligopoly markets and the legal terminology 'tacit coordination' to describe this outcome arising without any direct combination between the parties. ${ }^{1}$ The problem of oligopoly pricing and the problem of collusion - arriving at a mutually agreeable price and maintaining it in the face of entry and temptations to cheat - are essentially the same. ${ }^{2}$ As shown by Posner, the oligopoly structure of the market is just one of the conditions favourable to collusion, among others such as: inelastic demand at competitive price; buying side of the market nonconcentrated; standard non-durable product; principal firms selling at the same level in the

\footnotetext{
* MPhil/PhD Candidate, University College London, Faculty of Laws. I would like to thank Dr Laíse da Correggio, Dr Valerio Torti and Professor Ioannis Lianos for their valuable comments. Any errors remain, of course, my own.

${ }^{1}$ As suggested by Richard Whish and David Bailey, Competition Law (OUP 2008) 549-550; Marc Ivaldi and others, The Economics of Tacit Collusion, Final Report for DG Competition, European Commission (2003) 4.

${ }^{2}$ Richard Posner, Antitrust Law (2nd edn, The University of Chicago Press 2001) 60, 69.
} 
chain of distribution; co-operative practices; price competition more important than other forms; similar cost structures and production processes. ${ }^{3}$

Collusion is sustainable only if firms put sufficient weight on future profits (represented by the discount factor) in order to sacrifice short-term gains, such as in growing markets with high barriers to entry. ${ }^{4}$ Frequent interaction and price adjustments facilitate collusion while lack of transparency makes it more difficult. ${ }^{5}$ In summation, the basic challenges for firms that want collusive price/quantities with or without combination are:

i) identifying mutually beneficial strategy and outcome, since market perceptions may vary;

ii) monitoring adherence and detecting deviation, eg increasing market transparency; ${ }^{6}$

iii) punishing deviations with effective and credible sources, (retaliation) ${ }^{7}$ such as recourse to a 'trigger price', below which a price war begins. ${ }^{8}$

As a starting point, I briefly analyse the so-called facilitating practices (FPs) in oligopoly markets. ${ }^{9}$ Co-operative strategic behaviour means the actions taken by rival firms in their own self-interest in order to raise the oligopoly price closer to the monopoly level. ${ }^{10}$ As stated by Gavil and others, firms can take unilateral decisions, understood as efforts to change the structure of the market to facilitate collusion. ${ }^{11}$

The so-called FPs relate to 'the conduct by firms ... that falls somewhere between an explicit, 'hardcore' cartel agreement and pure and simple oligopolistic interdependence and helps firms to reduce uncertainty in the market and coordinate their conduct more effectively'. ${ }^{12}$ In the drive to increase gains, undertakings develop ways to coordinate while creatively complying with case law and evading the rigour of the rules. Most of the FPs I shall report actually try to create or emulate the described 'favourable conditions' to reach the three challenges above, as to artificially reinforce the oligopoly structure of the market.

\footnotetext{
3 ibid 69-79.

${ }^{4}$ Ivaldi and others (n 1) 8, 27.

5 ibid $22,27$.

${ }^{6}$ Okeoghene Odudu, The Boundaries of EC Competition Law (OUP 2006) 95.

${ }^{7}$ Ivaldi and others, (n 1) 6-7.

${ }^{8}$ Michael G Vita, 'Fifteen Years after Ethyl: The Past and Future of Facilitating Practices' (2000-2001) 68 Antitrust Law Journal 1005.

${ }^{9}$ See OECD, Facilitating Practices in Oligopolies, Roundtables on Competition Policy. DAF/COMP (2008) 24.

${ }^{10}$ Dennis W Carlton and Jeffrey M Perloff, Modern Industrial Organization (4th edn, Prentice Hall 2005$) 379$.

${ }^{11}$ Andrew I Gavil, William E Kovacic and Jonathan B Baker, Antitrust Law in Perspective: Cases, Concepts and Problems in Competition Policy (2nd edn, West Academic Publishing 2008) 343.

12 OECD (n 9) 9.
} 
Another frontier for antitrust enforcement, ${ }^{13}$ dampening competition theories focus on strategic behaviour encouraging anticompetitive co-operation or discouraging vigorous competition by horizontal rivals particularly through a commitment to less aggressive conducts. ${ }^{14}$ In Baker's opinion, these theories and FPs are not exactly the same: while FPs apply when there are repeated games in non-co-operative settings, dampening competition relates to static settings, with low number of firms, no entry and almost no exogenous shifts in cost or demand pressing down prices. ${ }^{15}$ The European Commission Guidelines on Vertical Restraints (GVR) seem to adopt a convergent approach of these effects; ${ }^{16}$ thus, I shall treat them as the same phenomenon.

After outlining the traditional horizontal practices, I present FPs in a vertical context in the following categories: exchange of information in vertical relationships, parallel adoption of vertical restraints (with and without agreement) and individual adoption of vertical restraints. Although these kinds of vertical FPs are a specific facet of the general 'oligopoly problem', I defend its solution as more feasible by using article 101(1) of the TFEU $^{17}$ even absent either explicit coordination or exchange of information. In this regard, a non-exhaustive but illustrative comparative approach will be adopted in relation to Section 1 of the Sherman Act ('Section 1') and Chapter I of the UK Competition Act 1998.

I argue that the horizontal/vertical dichotomy, though dangerous, is still a useful notion. Therefore, two legal options are evaluated. The first one is the application of horizontal law to vertical restraints, 'stretching' the concept of agreement and concerted practices to accommodate bilateral or trilateral schemes. The second option is to use the vertical agreement's path, with no beneficial treatment under the vertical block exemptions (VBEs) $)^{18}$ or under article 101(3). I dwell on the standard of pleading and on the role of intent and, afterwards, I describe several types of vertical restraints with collusive effects, having recourse to the concepts developed. Finally, as to the enforcement perspective, I analyse the consequences of unlawfulness (fines and settlements) and briefly present alternative enforcement initiatives such as the use of Section 5 of the Federal Trade Comission Act (FTC) Act ('Section 5') and market investigations.

\footnotetext{
${ }^{13}$ Gavil, Kovacic and Baker (n 11) 397.

${ }^{14}$ Jonathan B Baker, 'Vertical Restraints with Horizontal Consequences: Competitive Effects of Most-FavoredCustomer Clauses’ (1996) Spring 64 Antitrust Law Journal 528.

15 ibid 529.

${ }^{16}$ OJ C130/1, para 100 b-c.

${ }^{17}$ Consolidated Version of the Treaty on the Functioning of the European Union [2008] OJ C115/47.

${ }^{18}$ Commission Regulation 330/2010 on the application of Article 101(3) to categories of vertical agreements and concerted practices OJ L102 1-7.
} 


\section{B. FACILITATING PRACTICES: GENERAL PANORAMA}

\section{Horizontal Context: Traditional View ${ }^{19}$}

Professor Hay categorises as FPs the following: firstly, when there is an agreement easily proved to implement them; secondly, where one observes parallel adoption of FPs, but each of several competitors independently uses them; thirdly, where only one of the firms engages in FPs, making it easier for the other oligopolists to act anticompetitively. ${ }^{20}$ Exchanges of price information between competitors when not supporting a cartel spread over the three categories and are a classical example of FPs. Discussions about current and future prices are characterised by EU law as price-fixing agreements as object in their own right. ${ }^{21}$ Also, an isolated exchange may constitute sufficient basis for a concerted practice. ${ }^{22}$

The Guidelines on the applicability of Article 101 to horizontal co-operation agreements $(\mathrm{GHC})^{23}$ contain a detailed section about exchange of information compiling EU Courts' case law and exemplifying the application of the object/effects duality and efficiencies under article 101(3).Price parameters and categories, and other data may be the object of parallel adoption, making competition softer. ${ }^{24}$ Restrictive agreements on terms and offers to consumers, such as level of discounts and advertisement, ${ }^{25}$ may be related to secondary aspects of competition; they are thus caught by article 101(1). ${ }^{26}$ These practices when adopted in agreement do not raise questions on the establishment of a violation. ${ }^{27}$

Posner $^{28}$ and Turner ${ }^{29}$ agree that, in order to establish a violation of the Sherman Act,${ }^{30}$ it is unnecessary that the sellers had agreed to establish an FP. However, both Boise and Cascade ${ }^{31}$ and DuPont ${ }^{32}$ showed the US Courts' reluctance to accept the ban of parallel

\footnotetext{
${ }^{19}$ For a more extensive comparative approach see Sigrid Stroux, US and EC Oligopoly Control, International Competition Law Series Set (Kluwer Law International 2004), ch 6-7.

${ }^{20}$ OECD (n 9) 142.

${ }^{21}$ Whish (n 1) 524-525.

22 Case C-8/08 T-Mobile Netherlands BV and Others $v$ Raad van bestuur van de Nederlandse Mededingingsautoriteit [2009] ECJ ECR I-4529 para 59.

${ }^{23} \mathrm{OJ} \mathrm{C} 11 / 1$.

${ }^{24}$ Massimo Motta and others, 'Identical price categories in oligopolistic markets: Innocent behaviour or collusive practice?' Report written for the Autorità Garante della Concorrenza e del Mercato July 30 (2004) 12; Carlton and Perloff (n 10) 379-385.

${ }^{25}$ Whish (n 1) 532-533; US Contribution in OECD (n 9) 116-117.

${ }^{26}$ Whish (n 1) 522.

${ }^{27}$ US Contribution in OECD (n 9) 121; United States v Airline Tariff Publishing Co, 1994-2 Trade Cas (CCH) 70,687 (DDC August 10, 1994); see http://www.usdoj.gov/atr/cases/dir23.htm.

${ }^{28}$ Posner (n 2) 92.

${ }^{29}$ Donald F Turner, 'The Definition of Agreement under the Sherman Act: Conscious Parallelism and Refusals to Deal' (1962) 75 Harvard Law Review 675.

${ }^{30}$ For a general discussion see: William H Page, 'Facilitating Practices and Concerted Action Under Section 1 of the Sherman Act', in Keith N Hylton (ed) Antitrust Law and Economics (Edward Elgar 2010).

${ }^{31}$ Boise Cascade Corp.v Federal Trade Commission, 637, F 2d 573 9th Circuit 1980.
} 
but non-agreed adoption of various FPs. Less clear is when practices are adopted individually. Posner comments that publicly announced policy of matching any competitor's price cut and public discussions of the right price 'should be scrutinized carefully' ${ }^{33}$

Advance notice of price increases may be used to avoid the first firm's disadvantage in raising prices. ${ }^{34}$ It signals to other players the firm's future policy, facilitating tacit coordination in oligopolistic markets. ${ }^{35}$ An understanding that firms in a market will follow the signal from time to time emitted by the price leader can amount to tacit coordination, branded as an agreement or concerted practice under article 101 and Chapter I prohibition. ${ }^{36}$ Also, the mere receipt of information already reduces uncertainty and may amount to a concerted practice. ${ }^{37}$

\section{Vertical Context}

Separation between suppliers and dealers can lead to higher prices than vertical integration if vertical restraints are seen as a commitment to less aggressive competition. ${ }^{38}$ Concerns about the collusive effects of vertical restraints derive from their impact in the modelling/strengthening of the market structure. That is why we can frame them as FPs. Discussion of current and future prices and other commercial strategies may also occur in a vertical context. In fact, exchange of information is in the essence of every vertical relationship, under the obligation of the performance of vertical contracts. ${ }^{39}$ It gives rise to competition concerns when: a) the information is passed on to competitors through indirect contact by means of downstream/upstream common supplier/distributor/agent or; b) the upstream/downstream contractor is also a competitor. ${ }^{40}$ In distribution chains, some antitrust cases in the US and in Europe have been brought under the general heading of hub and spoke arrangements (HSAs). This occurs where, by means of one supplier or one retailer, two or

\footnotetext{
${ }^{32}$ DuPont de Nemours and Co. v Federal Trade Commission, 729, F 2d 128 2nd Circuit.1983. For a more extensive discussion see Rudolph JR Peritz, 'Toward an Expansive Reading of FTC Act $\S 5$ : Beyond the Sherman Act and an Ex Post Model of Enforcement', NYLS Legal Studies Research Paper 08/09 No 5 (July, 2009) 3.

${ }^{33}$ Posner (n 2) 87, 92.

${ }^{34}$ Carlton and Perloff (n 10) 380.

${ }^{35}$ Albertina Jones and Brenda Suffrin, EC Competition Law - Text, Cases and Materials (OUP 2008) 916.

${ }^{36}$ Whish (n 1) 550.

37 Albertina Albors-Llorens, 'Horizontal Agreements and Concerted Practices in EC Competition Law: Unlawful and Legitimate Contacts Between Competitors', (2006) 51:4 Antitrust Bulletin 866; Jones and Suffrin (n 35) 917; Case C-48/69 ICI and Others v Commission (Dyestuffs) [1972] ECR-619; Joined Cases C-89/85, C104/85, C-114/85, C-116-117 and C-125-129/85 Ahlström Osakeyhtiö and others $v$ Commission (Woodpulp II) [1993] ECR I-1307.

${ }^{38}$ Baker (n 14) 529.

${ }^{39}$ Peter Whelan, 'Trading Negotiations between Retailers and Suppliers: A Fertile Ground for Anti-competitive Horizontal Information Exchange?'(2009) December 5(3) European Competition Journal 823.

${ }^{40}$ See Section $\mathrm{D}(6)$ of this paper.
} 
more retailers or suppliers communicate future market intentions or become aware of them, arrange common strategies or fix their wholesale/retail prices.

The famous HSA in Interstate Circuit ${ }^{41}$ involved film producers/distributors 'compelled' to apply a policy favourable to an expensive first-run theatre, to the detriment of cheap subsequent-run theatres. Butz and Kleit argue that the collusive outcome could have been achieved without an inference of agreement between distributors because it was in their own interest to do so. ${ }^{42}$ In the 1990 s, Toys "R" Us (TRU) ${ }^{43}$, the largest US toy retailer, successfully convinced suppliers to restrict the range of products they sold to its competing warehouse discounting stores. The FTC brought an action challenging not only the vertical contracts but also the 'orchestration' of a horizontal agreement, since the suppliers would only have incentive to leave the warehouse if their competitors also did. According to Scherer, ${ }^{44}$ the FTC rejected the free-rider defence as TRU's promotional effort was already largely compensated by the manufacturers. ${ }^{45}$ In Europe, Musique Diffusion Francaise ${ }^{46}$ comprised a HSA involving Pioneer electronic products distributors in France that complained about parallel imports. Pioneer communicated these complaints to its exclusive dealers and organised meetings to control the situation.

Two paradigmatic UK cases involved indirect contact via an intermediary. ${ }^{47}$ In Replica Football Kits, ${ }^{48}$ the HSA was created as the result of a complaint from a powerful licensor and retailer (Manchester United - MU) to a supplier of replica football shorts and Tshirts (Umbro) that it was being undercut by some competitors. MU was going to leave the supplier unless it convinced others to raise their prices by enforcing its recommended retail price (RRP). ${ }^{49}$ Umbro then put pressure on its retailers not to discount the price of the football kits. A HSA and several vertical agreements between Umbro and its retailers led to the imposition of fines.

\footnotetext{
${ }^{41}$ Interstate Circuit Inc. v US, 306 US 08 (1939).

42 David A Butz and Andrew N Kleit, 'Are Vertical Restraints Pro- or Anticompetitive? Lessons from Interstate Circuit', (2001) April Journal of Law and Economics, Vol 44, No 1,131-157.

${ }^{43}$ Toys " $R$ " Us, Inc v Federal Trade Commission, 221 F 3d 928 (2000).

${ }^{44}$ Frederic M Scherer, 'Retailer-Instigated Restraints on Supplier's Sales: Toys "R" Us (2000)', in John E Kwoka and Lawrence J White (eds), The Antitrust Revolution: Economics, Competition, and Policy (OUP 2004) 382.

${ }^{45}$ In a contrary position, see Butz and Klein (n 42) 156-157.

${ }^{46}$ Case C-100-103/80 SA Musique Diffusion Francaise v Commission [1983] ECR 1825.

${ }^{47}$ Whelan (n 39) 836.

${ }^{48}$ OFT No CA98/06/2003 Football Kit price-fixing, OFT Decision of 1 Aug 2003 [2004] UKCLR 6; JJB Sports Plc [2004] CAT 17; Argos Ltd, Littlewoods and OFT, JJB Sports and OFT [2006] EWCA Civ 1318.

${ }^{49}$ Whelan (n 39) 825.
} 
Hasbro, a toy producer, was concerned in $\operatorname{Argos}^{50}$ that the reduced margin for its retailers might press it to lower its prices, and thus established a RRP policy. The cooperation of Argos, the main retailer and price setter, and Littlewoods, main competitor of Argos, was essential so Hasbro held individual conversations reassuring that the other one would follow the suggested price. The overall HSA was composed by two bilateral vertical agreements between each of the parties and a trilateral agreement. The GHC mentions that indirect information exchange through third parties may involve the parties' suppliers or retailers. ${ }^{51}$ This means that the Commission is willing to apply the same general principles to HSAs.

As to other vertical restraints, the concern with tacit coordination is present in the GVR in the following references: exclusion from the VBE of vertical agreements entered into between competing undertakings $;{ }^{52}$ collusion derived from agency agreements $;{ }^{53}$ softening of competition and facilitation of tacit coordination reducing inter-brand and intra-brand competition; ${ }^{54}$ express inclusion of explicit and tacit collusion and relationship with market structure ${ }^{55}$ analysis of network of agreements and behaviour indicating tacit coordination; ${ }^{.6}$ single branding; ${ }^{57}$ limited distribution agreements; ${ }^{58}$ category management; ${ }^{59}$ and RPM. ${ }^{60}$ Finally, while vertical practices adopted in parallel should be scrutinised, practices adopted individually can constitute focal points, that is, qualitatively identifiable and unambiguous signals as to the preferred outcome, observable by other firms, and constituting the selfevident way to behave. ${ }^{61}$ It appears that if unilateral price announcements may amount to concerted practices, individually adopted vertical practices should also do.

\section{DISCUSSING SUBSTANTIVE CATEGORIES}

\section{The Horizontal/Vertical Dichotomy}

First of all, the need to address the horizontal/vertical bifurcation derives from the propagated view that antitrust authorities should choose horizontal practices as enforcement priorities.

\footnotetext{
${ }^{50}$ OFT No CA98/8/2003 Hasbro UK Ltd/Argos Ltd/Littlewoords Ltd, OFT Decision of 21 Nov 2003 (CP/048001). Argos \& Littlewoods v OFT [2005] CAT 13. Argos and Others and OFT (n 48).

${ }^{51}$ See paragraph 55 of the Guidelines (n 23).

52 VBE (n 18) art 2(4); GVR (n 16) para 27.

${ }^{53}$ GVR (n 16) para 20.

54 ibid para 100 (ii, iii).

55 ibid paras $101,115$.

56 ibid para 121.

57 ibid paras 130,134 .

${ }^{58}$ ibid paras 151, 154, 157, 166, 168, 175, 178, 181, 182.

${ }^{59}$ ibid paras 211, 212.

${ }^{60}$ ibid paras 224, 227.

${ }^{61}$ Stroux (n 19) 28.
} 
Over-simplification, such as 'vertical good, horizontal bad', may be dangerous for the future of antitrust because it ignores the potential horizontal effects of vertical restraints. ${ }^{62}$ Nevertheless, it is recognised that the categories bring some degree of legal certainty, especially concerning the allocation of the burden of proof and are useful to antitrust resource management. ${ }^{63}$

Arguably Leegin ${ }^{64}$ reinforced the formalist approach and 'extended the scope of the dichotomy to price restrictions ${ }^{65}$ since it was decided that vertical RPM was then to be subjected to a rule of reason while horizontal price fixing should be kept following a per se rule. Instead of the bifurcation, Lianos ${ }^{66}$ suggests the adoption of new categories such as dealer-initiated, as opposed to manufacturer-initiated, distribution restraints. Generally, supplier-led restraints could follow a more lenient approach because suppliers' interests coincide with consumers', ${ }^{67}$ except where there is upstream market power. The real antitrust concern should be to identify the source of market power (upstream/downstream) and evaluate collusive or exclusionary effects that harm consumers, though these may come together in concrete challenges. ${ }^{68}$ The problem is that collusion has been traditionally a problem labelled 'horizontal', though the per se/object approach is not always adequate. It is then defensible that vertical restraints should not be analysed by object, let alone per se, but by its likely effects (or under a rule of reason).

\section{The Concept of Agreement}

The idea of 'agreement' has been and will continue to be relevant to antitrust, despite the more economic approach. There are jurisdictions in which 'agreement' is not needed (eg in Brazil), ${ }^{69}$ but the two most important systems rely on those categories and when 'agreement' or a proxy thereof is present, any antitrust case is stronger. It is true that pure tacit coordination does not amount to agreement. ${ }^{70}$ In the American context, though, conscious

\footnotetext{
62 Baker (n 14) 534; Ioannis Lianos, 'The Vertical/Horizontal Dichotomy in Competition Law: Some Reflections with Regard to Dual Distribution and Private Labels', in Ariel Ezrachi and Ulf Bernitz (eds), Private Labels, Brands and Competition policy (OUP 2009) 186.

${ }^{63}$ Lianos (n 62) 186.

${ }^{64}$ Leegin Creative Leather Products, Inc v PSKS, Inc, 551 US 877 (2007) (Supreme Court).

${ }^{65}$ Lianos (n 62) 180.

${ }^{66}$ Lianos (n 62) 182.

${ }^{67}$ See also Ioannis Lianos, 'Collusion in Vertical Relations under Article 81(1)' (2008) 45(4) Common Market Law Review 1061.

${ }^{68}$ See Toy "R" US (n 43); Willard K Tom, David A Balto and Neil W Averitt, 'Anticompetitive Aspects of Market-Share Discounts and Other Incentives to Exclusive Dealing' (1999-2000) 67 Antitrust Law Journal 620. ${ }^{69}$ Law 12529 of 30th November 2011 (Brazil), Article 36.

70 Turner (n 29) 706.
} 
parallelism may be evidence of agreement (plus-factor) when facts reveal that decisions were interdependent. ${ }^{71}$

Posner advocates that tacit coordination is not an unconscious state and that a meeting of minds or mutual understanding, even without overt communication, involves an offer accepted by the action of the rivals, and therefore a concerted action. ${ }^{72}$ However, completely independent conducts or tacit coordination of pricing in reaction to external shocks should be unobjectionable. ${ }^{73}$ In fact, absent communication, there must be some culpable act. Here, Hay's effort to make the concept of tacit coordination meaningful and operational using the idea of FPs as culpable acts becomes relevant. ${ }^{74}$ In the US, as reported by Page, the concept of 'tacit collusion' was loosely equated with oligopolistic price coordination and conscious parallelism and considered not unlawful in itself. ${ }^{75}$

Based on that, Hay states the presence of certain plus factors should serve actually to define a tacit agreement rather than permit an inference thereof. ${ }^{76}$ Thus, if the same parallel conduct led to supra-competitive pricing and depended on certain actions taken by the group of firms to facilitate tacit coordination, its adoption would be culpable, leading to the finding of an unlawful tacit agreement, absent any business justification. ${ }^{77}$ In fact, no agreement to reach the practice is necessary because we already have 'agreement' in the 'coordination of activity through inappropriate means'. ${ }^{78}$ Other plus factors, which are not FPs, would continue to serve as evidence of an explicit agreement.

\section{The Concept of Concerted Practice}

In the EU, there is a concerted practice when undertakings concert with each other, eg by direct or indirect conducts, aimed at knowingly removing uncertainty as to future market behaviour. Since Hüls ${ }^{79}$ the Commission does not need to demonstrate the practice was put into effect: the information exchanged is presumed to have been taken into account, subject to rebuttal. ${ }^{80}$ Although it is claimed that a concerted practice should be equated to the finding

\footnotetext{
71 ibid 658.

72 Posner (n 2) 94, 97.

73 ibid 96.

${ }^{74}$ George A Hay, 'Horizontal agreements: concept and proof' (2006) 51:4 Antitrust Bulletin 896, 900; OECD (n 9) 9.

${ }^{75}$ William H Page, 'Twombly and Communication: the Emerging Definition of Concerted Action Under the New Pleading Standards' (2009) 5(3) Journal of Competition Law and Economics 443. See Brooke Group Ltd. $v$ Brown and Williamson Tobacco Corp., 509 US 209, 227 (1993).

${ }^{76}$ Hay (n 74) 895.

77 ibid 902.

${ }^{78}$ ibid 913, citing In re Coordinated Pretrial Proceedings in Petroleum Prods. Antitrust Litig, 906 F2d 432,444 (9th Cir 1990).

${ }^{79}$ Case C-199/92 Hüls AG v Commission of the European Communities [1999] ECR-4287.

${ }^{80}$ Albors-Llorens (n 37) 847, 866. See T-Mobile (n 22) paras 43, 52.
} 
of an agreement by circumstantial evidence, it is not a residual category and must catch something that agreement does not. ${ }^{81}$ After rejecting a notion of concerted practice that requires common intention while relying on different evidence to agreement, Odudu adopts a notion that focuses on reductions of uncertainty and dispenses with common intention. ${ }^{82}$ In fact, this interpretation is the only interpretation that ensures autonomy of the concept of concerted practice.

Under current EU law, the standard is very high in the absence of reciprocal communication and low in its presence, as T-Mobile ${ }^{83}$ has reinforced. Therefore, it is only necessary to show that an isolated act of communication knowingly reduces uncertainty, if the companies remain active in the market. On the other hand, parallelism of market conduct only explained by tacit coordination amounts to a concerted practice. I conclude that it is possible to reconcile the two standards if the lack of good evidence of communication, such as using indirect means like an FP to communicate prices or reveal market intentions, can be compensated by a high degree of market parallelism, with existent but weak business justification. Therefore, parallel adoption of FPs may be unlawful when it substantially amounts to a restrictive agreement/concerted practice.

\section{Vertical Agreement and Concerted Practice}

In a vertical context, many practices escape application of article 101, leading to underenforcement of antitrust law 'if there is no evidence of a formal invitation to collude by the supplier and acquiescence by the dealers' ${ }^{84}$ While the concept of concerted practice is more expandable and operational in relation to horizontal practices, the concept of agreement is restricted and mainly applied to vertical agreements. ${ }^{85}$ However, apart from HSAs, the concept of 'concerted practice' has been used in a vertical context as a residual category when, despite no clear evidence of agreement between the supplier and the distributor, there is evidence of coordination; or sanctioning apparently unilateral practice implementing a preexisting vertical agreement, not necessarily anticompetitively - here, no acquiescence is required. ${ }^{86}$

The debate about the scope of unilateral conduct and the expansion of the concept of agreement is still relevant in the EU. In Bayer $^{87}$ the expansive trend has reverted, since there

\footnotetext{
${ }^{81}$ Odudu (n 6) 71, 81.

82 ibid 80-83.

83 (n 22).

${ }^{84}$ Lianos (n 67) 1059.

85 ibid 1051.

86 ibid 1052-1055.

${ }^{87}$ Case T-41/96, Bayer v Commission (Order) [1996] ECR II-381; (Judgment) [2000] ECR II-3383.
} 
was no 'distribution network to which the measures adopted by Bayer could be ascribed' ${ }^{88}$ The European Court decision in Volkswagen ${ }^{89}$ brought an interpretation of the aims of a neutral agreement, based on the legal and economic context of the relationship between the parties. ${ }^{90}$

As to the application of article 101(3) to vertical relations, it should be narrow in oligopoly markets since the disposition requires no substantial elimination of competition and the Commission's regulation contains market share caps ${ }^{91}$. In oligopolies of four firms, each with 20-25\%, generally the VBEs could be withdrawn, especially in case of parallel adoption of vertical restraints. One indication of agreement would be if a substantial and significant percentage of the retailers of the distribution network have implemented the scheme. ${ }^{92}$ Interestingly, this could lead to 'a finding of a vertical agreement with the supplier, while it could not be sufficient evidence to infer a horizontal agreement or concerted practice between the distributors' ${ }^{93}$

\section{The Role Of Intent}

Standards of pleading and of proof are different depending on the system. In this regard, the category of 'intent' has achieved a prominent role in horizontal and vertical contexts in both EU and US doctrine and case law.

In Page's opinion, concerning Section 1, the parallel adoption of a FP cannot exclude the possibility of independent action by rivals, failing to fulfil the Matsushita standard. ${ }^{94}$ Page argues that US courts pre- and post-Twombly ${ }^{95}$ have implicitly adopted a definition of concerted action requiring communication of intent and reliance, especially when communication is private, repeated and related to present/future actions. ${ }^{96}$ This constitutes 'a tangible, culpable action that differs from the actions of firms in an ordinary competition or in a simple conscious parallelism' ${ }^{97}$ Some FPs may themselves involve communications, thus meeting the underlined definition. ${ }^{98}$ The question that remains is whether there are FPs that do not involve communications, which would result in under-enforcement. The discussion of

\footnotetext{
${ }^{88}$ Lianos (n 67) 1043-1044.

${ }^{89}$ Case C-74/04, Commission v Volkswagen AG [2006] ECR 1-6585 paras 45, 48.

${ }^{90}$ Lianos (n 67) 1046-1047.

${ }^{91}$ Whish (n 1) 556.

92 Lianos (n 67) 1074.

93 ibid 1066.

${ }^{94}$ Page (n 30) 43.

95 Bell Atlantic Corp v Twombly, 127 S Ct 1955, 1965 (2007) cited by Page (n 75) 447.

${ }^{96}$ Page (n 30) 35, 38.

${ }^{97}$ Page (n 75) 452.

${ }^{98}$ Page (n 30) 29.
} 
intent can also be illustrated by means of the already cited UK cases. In Argos ${ }^{99}$ and Football Kits $^{100}$, the supplier (B) was acting as an intermediary of price pressure among retailers (A and $\mathrm{C}$ ). The role of the supplier in a HSA is comparable to the facilitator of an agreement, ${ }^{101}$ subject to fines if her actions are intentional, if she purposefully passes on information or requests, or negligent, if she does not take the necessary duty of care in handling information. There is an EU duty on vertical participants not to encourage communication between horizontal actors. ${ }^{102}$

Whelan depicts three extra scenarios with reference to the knowledge of the role of the supplier in the arrangement: 1) both retailers (A and C) are fully aware thereof; 2) one retailer (A or C) is not aware; 3 ) both are not aware. ${ }^{103}$ While the two first options do not pose a problem, the third is at the root of the difference between the Competition Appeal Tribunal (CAT) and the Court of Appeals (CoAp) approaches to the decision of the Office of Fair Trading (OFT, predecessor of the Competition and Markets Authority). While the former defends that constructive knowledge (reasonable foreseeability) of the role of the supplier is enough to constitute a concerted practice, the latter requires that actual knowledge for both retailers has to be shown. ${ }^{104}$

In Whelan's view, both approaches are deferential to legitimate vertical discussion and the option is a matter of policy and choice of errors to minimize. Albors-Llorens argues that the CAT's position of 'reasonable expectations' 'dilutes the strength of the requirement laid down in Dyestuffs' (knowingly substitutes co-operation for competition). ${ }^{105}$ Also, of concern is the limited scope of defences retailers have at their disposal: the sender (A) is obliged to show that price intentions were revealed for a legitimate purpose and could have not foreseen that the intermediary (B) would use information to affect market conditions. ${ }^{106}$ The receiver (C), who did not ask for information, has to distance itself completely and publicly from the exchange.

When the receiver $(\mathrm{C})$ requests or forces information from the supplier (B), only when the sender (A) has knowledge will the granting of information make the flow horizontal. ${ }^{107}$ This

\footnotetext{
99 (n 50).

100 (n 48).

${ }^{101}$ Whelan (n 39) 834. See case T-99/04 AC-Treuhand AG v Commission [2008] WLR (D) 229 para 150.

102 Odudu (n 6) 90.

${ }^{103}$ Whelan (n 39) 833, 834.

104 ibid 837.

105 Albors-Llorens (n 37) 871.

106 ibid 874.

107 ibid 838, 839.
} 
may open up room for the role of intent in purely vertical agreement analysis and the following recognition by the CoAp is important:

[If] there were two separate agreements or concerted practice between [the parties] ... knowledge of what was going on as regards the other agreement or concerted practice, and the interdependent relationship between the two, would mean that each of the vertical concerted practices was capable of being regarded as being as serious a breach as if there had been a trilateral concerted practice with horizontal operation. ${ }^{108}$ The definition of antitrust agreement, at least in a vertical setting, should not be focused on 'the exchange of consent or a meeting of minds between the parties but should instead identify situations of induced or coerced conduct, as opposed to purely unilateral one'. ${ }^{109}$ In fact, when there is inducement or coercion, vertical competition is restricted. Finally, as suggested by Lianos, it is better first to look for evidence of a horizontal agreement/concerted practice between dealers or suppliers, by means of an intermediary and secondly, if it is not possible to find one, to look for a vertical agreement. ${ }^{110}$

This two-step procedure is the most appropriate. A firm's first effort is to signal to their competitors, despite using a vertical relation; thus, antitrust should focus on what firms prioritise. If one considers the parallel adoption of vertical restraints by almost all the suppliers/dealers, intent can play its role in finding horizontal agreement/concerted practice. Anticompetitive intent is present in the use of FPs to communicate a specific commitment to price or to the softening competition towards other suppliers/dealers. It is a new kind of HSA, which does not involve flow of information or requests to change conduct. In the US, it is interesting to see how this might be analysed under the Twombly requirements. If 'communication' cannot be established, each vertical relation and its aggregate effect should be analysed to establish a vertical agreement restricting horizontal competition based on inducement or coercion.

\section{VERTICAL RESTRAINTS WITH COLLUSIVE EFFECTS}

\section{Most-Favoured-Customer Clauses}

In a vertical context, a common object of scrutiny is the most-favoured-customer - MFC (also most-favoured-nation - MFN) clause in a sales contract, which guarantees the buyer that the seller is not currently selling or will not sell in the future at a lower price to another

\footnotetext{
${ }^{108}$ See Argos (n 50) para 105, emphasis added.

${ }^{109}$ Lianos (n 67) 1044.

110 ibid 1073-1075.
} 


\section{Vertical Restraints Facilitating Horizontal Collusion: 'Stretching' Agreements in a Comparative Approach}

buyer. ${ }^{111}$ One variation is the meeting-competition clause in a long-term supply contract or price matching in an advertisement, which gives assurance to the buyer that if another seller offers a lower price, it will match it or release the buyer from the contract. ${ }^{112}$ In both cases, there is a commitment from the seller and no commitment from the buyer. ${ }^{113}$ It is a clause inside a contractual arrangement that constitutes a vertical restraint. Used to give comfort to smaller buyers, it can have equivalent effects of a rebate or an exclusivity clause. They function as if customers are policing price levels; thus, they can also be framed as constituting information exchange. ${ }^{114}$

Even when buyers voluntary agree to some practices, it does not mean that they collectively will benefit from them; they would be better off if none accepted. ${ }^{115}$ As stated in Gavil and others, although MFC clauses 'may appear favorable to individual buyers, their widespread use may be harmful to buyers as a group ... Each firm that makes such a promise raises its own cost of cutting price. It effectively ties its own hands so that it won't have an incentive to cheat making a price war less likely'. ${ }^{116}$ Posner comments with wit that sellers might even pay buyers to agree to such clauses. ${ }^{117}$

In GE/Westinghouse, ${ }^{118}$ both companies promised electric equipment customers that if any got a lower price, the firm would retroactively give that lower price to the original customer, by refunding the difference. In DuPont, ${ }^{119}$ when DuPont and Ethyl (and sometimes PPG) offered MFC clauses, the FTC unsuccessfully tried to bring the case as a unilateral practice using Section 5, among other challenges. ${ }^{120}$

Baker generally criticises the overreliance in certain efficiencies of MFC clauses such as lowering search costs for uniformed weak buyers and assurance to long-term contracts. ${ }^{121}$ In the FPs scenario, he reports MFC clauses in drugs reimbursement contracts of pharmacies with RxCare, a dominant network. ${ }^{122}$ It imposed that if pharmacies accepted lower reimbursements from others, they would have to accept lower rates from RxCare, which

\footnotetext{
${ }^{111}$ Carlton and Perloff (n 10) 141.

112 ibid.

${ }^{113}$ Einer Elhauge, 'How Loyalty Discounts Can Perversely Discourage Discounting' (2009) 5(2) Journal of Competition Law and Economics 193.

114 Stroux (n 19) 33.

115 Elhauge (n 113) 217.

${ }^{116}$ Gavil, Kovacic and Baker (n 11) 343-344.

${ }_{117}$ Posner (n 2) 81.

${ }^{118}$ Hay (n 74) 113-115. See United States v GE Co, 565 F 2d 208 (ED Pa 1977).

119 (n 32).

${ }^{120}$ For details on the practice, see Hay (n 74) 115-118; for an economic analysis, see Vita (n 8).

${ }^{121}$ Baker (n 14) 531-534.

122 ibid 522.
} 
discouraged selective discounting. ${ }^{123}$ As to the raising rivals cost theory, firms that want to reach coordination press for MFC clauses by their suppliers to assure that "new entrants and existing competition will not be able to obtain lower costs by getting better prices from those suppliers' ${ }^{124}$ The idea is that MFC clauses as vertical restraints increase the marginal costs of certain entrant firms inducing them to reduce output or raise prices; finally, the remaining downstream firms, who pressed for the clauses, can also do the same without fear that rivals would undermine the 'co-operation'. ${ }^{125}$

In the GVR, MFC clauses are described as 'supportive measures' to enforce RPMs towards buyers. ${ }^{126}$ Nevertheless, since it is unlikely that these clauses are a product of a horizontal agreement, ${ }^{127}$ they should be attacked, when anticompetitive, as an unlawful vertical agreement both under Section 1 and article 101(1). The restriction of competition is not between the parties of the agreement but the effects are FPs and softening competition among sellers. Legally, this should not matter, since a restrictive effect is found. ${ }^{128}$

\section{Loyalty Discounts}

Quantity requirements and price incentives often amount to exclusivity contracts and share the same effects. ${ }^{129}$ Loyalty discounting, the practice whereby discounts are granted based on the purchase of most or all of its requirements from the seller, is an example of that. In comparison to MFC and price matching clauses, there is a commitment to the buyer to acquire a high share of purchases and there is a new kind of commitment to the sellers: to maintain a price difference between agreeing and non-agreeing buyers. ${ }^{130}$

Elhauge's approach proves that loyalty discounts produce anticompetitive effects by perversely discouraging discounting and matching rivals. Firms can raise prices above the competitive levels for both loyal and free buyers, even in different assumptions. ${ }^{131}$ There is less incentive to compete for free buyers, since any price reduction to win sales will also lower prices to loyal buyers, making it more costly to compete. ${ }^{132}$ Elhauge interestingly claims that loyalty discounts can have these kinds of anticompetitive effects even if: 1) buyers can breach or terminate commitments; 2) the requirements are substantially less than

\footnotetext{
${ }^{123}$ RxCare of Tenn, Inc File No 951-0059 Jan 191996.

124 Baker (n 14) 525.

125 ibid 523, 524.

${ }^{126}$ See GVR (n 16) para 48.

${ }^{127}$ Gavil, Kovacic and Baker (n 11) 347.

${ }^{128}$ In a contrary position, see G Monti, EC Competition Law (CUP 2007) 340.

${ }^{129}$ Tom, Balto and Averitt (n 68) 639.

${ }^{130}$ Elhauge (n 113) 193.

131 ibid.

132 ibid.
} 
$100 \%$; and 3 ) discounts are small (eg 1 to $3 \%$ ). ${ }^{133}$ The most welcome finding is that when multiple firms offer loyalty discounts, anticompetitive effects are exacerbated since there is even less incentive for each firm to undercut prices to capture the few uncommitted buyers available and the resulting equilibrium is less vulnerable to defection. ${ }^{134}$

This economically proves that loyalty rebates may constitute vertical FPs. Though this collusive effect is not directly mentioned in the GVR, the cumulative foreclosure analysis, adopted by the US Supreme Court cases and the GVR, has thus been shown to have a sound economic basis. ${ }^{135}$ This discount-discouragement effect is independent of any exclusionary ones and the rule of reason and an effects-based approach continue to be appropriate due to possible efficiencies. ${ }^{136}$ Like in MFC contexts, parallel loyalty rebate schemes do not tend to be adopted by formal horizontal agreements/concerted practices. Therefore, the vertical agreements' path seems more feasible, especially in cases where not all oligopolists adopt loyalty rebates, whenever there is a restriction of competition. A careful analysis under the rule of reason or article 101(3) should be carried out.

\section{RPM}

Despite common arguments that RPM is economically equivalent to non-price restraints, it has a special ability to facilitate tacit coordination. ${ }^{137}$ Manufacturers that want to collude often rely on indirect imperfect evidence, such as retail prices, to infer potential deviations, especially when they do not directly observe each other's behaviours. ${ }^{138}$ RPM allows manufacturers to control prices and detect deviations with certainty, although sometimes manufacturers prefer control with some flexibility, because retailers base their decisions on wholesale tariffs and changing local stocks on demand and cost. ${ }^{139}$ As an FP, RPM enhances the transparency of retail prices facilitating tacit coordination in case of imperfect observability of rivals. ${ }^{140}$ The upstream commitment to compete less aggressively with each other leads to higher retail prices when rivals are expected to become less aggressive as well: this effect is more prominent when RPM is adopted by multiple competing manufacturers. ${ }^{141}$

\footnotetext{
133 ibid 218, 219.

134 ibid 194.

135 ibid 220.

136 ibid 193, 194.

${ }^{137}$ Emanuele Giovannetti and David Stallibrass, 'Three Cases in Search of a Theory: Resale Price Maintenance in the UK' (2009) 5(3) European Competition Journal 647.

${ }^{138}$ Bruno Jullien and Patrick Rey, 'Resale price maintenance and collusion' (2007) 38(4) RAND Journal of Economics 996.

139 ibid.

140 ibid; See also Massimo Motta, Competition Policy: Theory and Practice (CUP 2004) 358, 359.

${ }^{141}$ Gavil, Kovacic and Baker (n 11) 397.
} 
As noted by Gavil and others, the Court in Leegin ${ }^{142}$ failed to address this dampening competition situation. ${ }^{143}$

Competition between manufacturers for scarce shelf space provides incentives for manufacturer-induced RPMs, but this may lead to anticompetitive effects such as entry deterrence in retailing, and protection of downstream rents. ${ }^{144}$ When only one firm of a retail duopoly adopts RPM, this interestingly leads to higher prices in the retail level. ${ }^{145}$ According to Shaffer's model, the retailer choosing RPM acts as price leader while the uncommitted firm acts as a price follower, with both retailers earning higher profits than in benchmark. ${ }^{146}$

Industry-wide RPM facilitates tacit coordination when a product is not normally sold with services or, although it may be, it does not 'need' to be sold with services, because inframarginal consumers are experienced enough to dispense with services. ${ }^{147}$ This test is also useful to differentiate RPM really imposed by seller or only nominally imposed by them, ${ }^{148}$ as an FP through dealer pressure. Minimum RPM can be used to prevent countervailing buyer power from exerting a constraining influence on monopoly pricing. ${ }^{149}$ Maximum RPM can also lead to higher retail prices, contrary to conventional wisdom that it is always used to correct the double-mark up problem. ${ }^{150}$

Moreover, selling through common agency or retailer might give rise to the joint maximizing prices being charged at equilibrium when a franchise fee is paid by the retailer to the manufacturer. ${ }^{151}$ First, when the retailer sets prices, it will behave as manufacturers sold directly to the final market and could maximise joint profits. ${ }^{152}$ In addition, even when RPM is allowed, the equilibrium to result is the collusive one because each manufacturer will take into account the final profit of the retailer when setting the price. ${ }^{153}$ In sum, evidence of a network of RPM agreements involving a significant share of the upstream supplier market makes plausible the theories of FPs in upstream collusion and dampening competition via

\footnotetext{
142 (n 64).

${ }^{143}$ Gavil, Kovacic and Baker (n 11) 397.

${ }^{144}$ Gregory Shaffer, 'Slotting Allowances and Resale Price Maintenance: A Comparison of Facilitating Practices' (1991) 22 RAND Journal of Economics 120, 121.

145 ibid 130 .

146 ibid 128.

${ }^{147}$ Lianos (n 62) 168.

${ }_{148}$ Posner (n 2) 88-89.

${ }^{149}$ Gregory Shaffer and Daniel P O’Brien, 'Vertical Control with Bilateral Contracts' (1992) 23 RAND Journal of Economics 306.

150 ibid 307.

${ }^{151}$ Motta (n 140) 358, 359.

152 ibid.

153 ibid.
} 
reciprocal relations. ${ }^{154}$ On the other hand, evidence of bargaining or market power of retailers and their role in instigating RPM lead to the plausibility of the theories of FPs in downstream collusion and downstream entry deterrence. ${ }^{155}$

In the EU context, paragraph 224 of the GVR mentions that RPM can facilitate tacit coordination among suppliers or buyers, while paragraph 227 mentions the risk of tacit coordination between suppliers derived from maximum and RRP when they serve as focal points. However, a finding of a vertical RPM agreement invariably bring the harsh consequences of an object approach. Since both Argos $^{156}$ and Football Kits ${ }^{157}$ were decided by object, no horizontal theory of harm was delineated: in Argos, it could only be FPs helping downstream collusion by retailers; in Football Kits, downstream entry deterrence of retailers and FPs helping upstream collusion of licensors were also a possibility. ${ }^{158}$ HSAs involving exchange of information on prices may be equivalent to HSAs establishing the adoption of RPMs, because in the latter, you also communicate an actual commitment to a price; thus, they may amount to a concerted practice. In any case, an (illegal) vertical agreement should only be found when a supplier and a distributor share the monopolistic return arising from the RPM. ${ }^{159}$ This would lead to only harmful RPMs being caught.

In the US, the parallel adoption of RPMs in several supplier-dealer relations with the result of refusing to deal with discounting retailers may recall case law related to the concepts of FP and amount to an unlawful conspiracy. ${ }^{160}$ Gavil and others. note that to avoid the qualification as 'agreement', two common practices developed: manufacturer's RRP and consignment sales, in which there is no passage of title or risk to the consignee, who acts as an agent. ${ }^{161}$ In any case, the parallel adoption of RRPs and maximum prices may also trigger the idea of horizontal agreement/concerted practice since the commitment by means of focal points may amount to communication.

\section{Advertisement Restraints}

Co-operative advertisement programmes (CAPs) are schemes between a manufacturer/distributor towards a retailer in which the former co-operates with the costs of advertisement of the latter. Minimum Advertised Prices (MAPs) are practices by which a

\footnotetext{
${ }^{154}$ Giovannetti and Stallibras (n 137) 653.

155 ibid.

${ }^{156}$ Argos (n 50).

${ }^{157}$ Football Kits (n 48).

${ }^{158}$ Giovannetti and Stallibras (n 137) 649-651.

${ }^{159}$ Lianos (n 67) 1070.

${ }^{160}$ Turner (n 29) 679-680.

${ }^{161}$ Gavil, Kovacic and Baker (n 11) 404, 405.
} 
distributor sets the minimum price to be shown in any jointly financed retailer advertisement. ${ }^{162}$ Some schemes may contain provisions that all advertisement regardless of sharing the costs must follow the rules, and more rigid programmes may include intra-store advertisement. If rules are breached, the retailer is subject to sanctioning by the manufacturer, such as the withdrawal of the amount, which may have drastic consequences. ${ }^{163}$ It constitutes a vertical FP since it helps to maintain retailer or wholesale prices high. Even if the retailer may sell the product at any price, she can no longer advertise her discounted prices; thus, consumer information is restrained, price competition is impaired and as a result, there is less pressure from the retailers for the manufacturers to cut wholesale prices. ${ }^{164}$ The effects of MAP may be comparable to RPM, ${ }^{165}$ and, especially when adopted in parallel by upstream firms, it helps to maintain tacit coordination between them. MAP programs are particularly problematic where dealers lose their freedom to determine actual resale prices and to advertise their prices out of the program. Good evidence of that is when adoption was in response to complaints due to excessive competition by retailers, who may help to police the scheme, denouncing discounters. ${ }^{166}$

These practices have been extensively analysed by US courts, which deemed them reasonable by circumventing the inflexibility of $\mathrm{Dr}$. Miles ${ }^{167}$ with forced arguments such as lack of evidence of 'agreement'. ${ }^{168}$ However, after Legin, ${ }^{169}$ they can be judged more 'on the merits'. ${ }^{170}$ In the FTC challenge of MAPs under Section $5,{ }^{171}$ the five largest USA music distributors imposed simultaneously and openly a similar rigid MAP policy toward retailers that led to an increase in $\mathrm{CD}$ prices. The main reason was that intense retail competition increased concentration in the industry, which might represent countervailing power to music distributors in the future. With less pressure, wholesale prices could be raised. Not only were the vertical agreements challenged, but also the horizontal aspect of facilitating an increase in the retail price; in the end, a settlement was reached without any admission of wrongdoing.

\footnotetext{
162 Martin A Asher, John A Del Roccili and Joseph P Fuhr, 'The Antitrust Implications of Minimum Advertised Pricing: The Case of the U.S. Music Industry' (2006) January Entertainment and Sports Law Journal 2.

${ }^{163}$ H Damian Elahi, 'Record Distributors' Minimum Advertised Price Provisions: Tripping Antitrust During Pursuit of Revenue, Control, and Survival in the Openly Competitive Digital Era' (2001) 21 Loyola Entertainment Law Review 450.

164 OECD (n 9) 115.

165 Asher, Del Roccili and Fuhr (n 162) 4.

166 ibid 3; Gavil, Kovacic and Baker (n 11) 404.

${ }^{167}$ Dr Miles Medical Co v John D Park \& Sons Co, 220 US 373 (1911).

${ }^{168}$ Gavil, Kovacic and Baker (n 11) 404.

169 (n 64).

${ }^{170}$ Gavil, Kovacic and Baker (n 11) 404.

${ }^{171}$ In the Matter of Sony Music Entertainment, Inc, 2000 WL689147 (FTC May 102000 ).
} 
The FP lessened competition between retailers, even though the suppliers imposed the practice; thus, a cautious inference of a horizontal case is recommended. ${ }^{172}$

With reference to the following class suits under the Sherman Act, Section 1 could be applicable in two settings. ${ }^{173}$ First, it should cover the parallel adoption of very similar MAP programmes, covering $80 \%$ of US market. To prove that, Elahi uses the traditional analysis of plus factors, such as the uniform wholesale price increase and the contemporaneousness and previous announcement of the adoption of the practices before the implementation day. ${ }^{174}$ In any case, that may resist Twombly's requirements of plausibility and fulfil the standard of meeting of the minds. Second, in a vertical analysis, an RPM agreement might be implied from the circumstances of the distributor-retailer interaction. ${ }^{175}$ In the EU context, the vertical relationship in the same industry, which included MAP policy, was also under investigation. The latter ended when the parties changed their practices. ${ }^{176}$

\section{Non-Price Restraints: Single Branding and Limited Distribution}

Exclusive territories (or exclusive distribution - 'I will sell only to you within a territory' ${ }^{177}$ ) and single branding (also called exclusive dealing - 'you will buy it only or mostly from me') are sources of strategic restraints that might keep prices high, in the presence of market power. ${ }^{178}$ Manufacturers might desire to make their distributors or retailers 'softer' competitors, relaxing inter-brand competition so as to achieve higher profits and final prices. ${ }^{179}$ Exclusive territorial clauses are visible and not easily renegotiated, expressing credible commitment. ${ }^{180}$ As shown in the FTC case Hale and Waterous, ${ }^{181}$ two water pump manufacturers imposed restraints of exclusivity covering $90 \%$ of the market for more than 50 years towards the producers of fire trucks. As a result, there were few reciprocal constraints and departure from market division was easily detectable. ${ }^{182}$ Nevertheless, Tom and others claim that concerns with collusive effects may occur even in short-term contracts because they remove much of the seller's incentive to give discounts. ${ }^{183}$

\footnotetext{
${ }^{172}$ US Contribution in OECD (n 9) 115.

173 Elahi (n 163) 452.

174 ibid 459-461.

175 ibid 467, 468.

${ }^{176}$ Asher, Del Roccili and Fuhr (n 162) 5; European Commission, 'Commission closes inquiry into CD prices after changes to business practices’ (Press Release IP/01/1212, 17 August 2011).

${ }_{177}$ Valentine Korah, EC Competition Law (9th edn, Hart Publishing 2007) 311.

${ }^{178}$ Motta (n 140) 348-352; Shaffer and O’Brien (n 149) 307.

${ }^{179}$ Motta (n 140) 348-352.

180 ibid 350.

${ }^{181}$ Hale Prods, Inc, No C-3694 (Federal Trade Commission) Nov 25 1996; Waterous Co, No C-3693 (Federal Trade Commission) Nov 221996.

182 Tom, Balto and Averitt (n 68) 619.

183 ibid 618.
} 
Allain and others show that exclusive dealing contracts makes collusion easier to sustain when interbrand competition is soft enough. ${ }^{184}$ Loss of variety is also a concern. ${ }^{185}$ Moreover, parallel use of exclusive dealing by suppliers makes monitoring of prices and discounts easier; this helps to maintain prices above competitive levels, at least in differentiated products. ${ }^{186}$

In the GVR, paragraph 130 is concerned with collusive effects derived from single branding and paragraph 134 suggests the withdrawal of VBE if individuals have less than $30 \%$ of market share, but there is cumulative effect. Concerning exclusive distribution, paragraph 151 mentions collusive effects in both supply and retail. Paragraphs 154 and 160 mention that a small number of suppliers may lead to tacit coordination, especially at the wholesale level and in the context of multiple exclusive dealerships, which is interestingly exemplified in paragraph 166. According to paragraph 157, buyer power increases the risk of tacit coordination in the buyer's side. Paragraph 168 mentions the risks of tacit coordination on both levels derived from exclusive customer allocation while collusive effects of selective distribution are covered by paragraph 175, with paragraph 178 emphasising tacit coordination of suppliers, and paragraph 181 underlining buying power as generating tacit coordination by dealers. Finally, paragraph 182 calls attention to the prohibition of non-compete obligation expressed in article 5(1)(c) of the VBEs if horizontal tacit coordination excludes less important suppliers.

The decision on whether the parallel adoption of single branding/exclusive distribution is an agreement or a concerted practice under Section 1 or article 101 depends on how widely communication is interpreted. If the option is to analyse the vertical agreement, in the EU, the analysis of the incentives of those who take the initiative of the restraint (supplier/dealer) should define whether BEs may be withdrawn. The technique of withdrawal to deal with tacit coordination seems to be derived less from the aggregate effect of the sum of market shares than from the fact that each and every one of the important suppliers/dealers has chosen to act in a parallel fashion in their own self-interest.

\footnotetext{
${ }^{184}$ Marie-Laure Allain, Claire Chambolle and Clémence Christin, 'Downstream Competition, Exclusive Dealing and Upstream Collusion' (2009) Workshop on Market Power in Vertically Related Markets, Toulouse, France, 16-17 Mar, 10.

185 Joshua D Wright, ‘Antitrust Law and Competition for Distribution', (2006) 23 Yale Journal of Regulation 176.

${ }^{186}$ Tom, Balto and Averitt (n 68) 618.
} 


\section{Category Management, Slotting Allowances, Private Label and Dual Distribution}

Category management (CM) occurs when a retail chain decides 'to manage its business on a category basis and appoints the leading manufacturer in the field as a Category Captain'. ${ }^{187}$ There are some questions about CM that involve FPs of a vertical nature. Firstly, there may be information exchange with collusive consequences, since distributors pass on information from other suppliers to the category captain, particularly relating to future promotions and advertisement plans. ${ }^{188}$ This would follow the approach analysed supra, including the kind of information passed on and the anticompetitive intent behind the practice.

Secondly, as pointed out by Wright, despite being less restrictive, CM is an alternative to exclusive dealing since 'it reduces the retailer's ability to deviate from the specified or implied desired level of promotional performance by placing those decisions in the hands of the category manager, or lowering the costs of detection as a result of the manager's increased involvement in shelf space allocation'. ${ }^{189}$ According to the new section on the GVR, ${ }^{190} \mathrm{CM}$ agreements are block exempted if the supplier/retailer has less than $30 \%$ market share, though in case of parallel appointment by retailers of the same category captain, a withdrawal is necessary.

Wright notes that manufacturer payments for promotion and exclusionary contractual mechanisms often come together. ${ }^{191}$ One phenomenon also relating to tactics in the retail sector consists of slotting allowances, fees paid by manufacturers to obtain retailer support by means of a two-part tariff in which the producer charges a high wholesale price but gives back profits in the form of an allowance to get shelf space in retail. ${ }^{192}$ At the same time, retailers commit to high marginal costs and announce their intention to be less aggressive in pricing. ${ }^{193}$

If inter-retailer competition is minimal, wholesale price discounts are more commonly adopted. ${ }^{194}$ If competition is intense, RPM will be adopted when contracts are not observable and slotting allowances will be used when they are observable. ${ }^{195}$ Thus, like RPMs, slotting allowances may constitute FPs to tacit coordination. ${ }^{196}$ While in the US they were challenged

\footnotetext{
${ }^{187}$ Lianos (n 62) 172.

${ }^{188}$ GVR (n 16) para 212.

${ }^{189}$ Lianos (n 62) 176.

${ }^{190}$ GVR (n 16) para 209.

${ }^{191}$ Wright (n 185) 169-177.

192 Shaffer (n 144) 120.

193 ibid 121.

194 Wright (n 185) 175.

195 Shaffer (n 144) 135.

196 ibid.
} 
in litigation, ${ }^{197}$ in the EU, there is a whole new section in the GVR dedicated to upfront payment to access. ${ }^{198}$

Commonly used today for different purposes, private label and dual distribution are not on their own vertical restraints but they may come together with them, which changes their analysis. ${ }^{199}$ This combination may result not only in exclusion but also in tacit coordination. Lianos cites them as examples of hybrid vertical/horizontal practices ${ }^{200}$ and presents the following definitions:

- Dual distribution occurs "when the manufacturer simultaneously sells to independent dealers and is also present at the distribution level of the commercialization process by supplying customers directly'. ${ }^{201}$

- $\quad$ Private Label refers to products sold under a retailer's brand, either on the retailer's own name or in an especially created brand. ${ }^{202}$ In the GVR, there are two references to private label. ${ }^{203}$

Concerning dual distribution, the manufacturer may have the incentive to impose price or non-price restraints on the retailers of his network competing with him, lowering their margins, which may harm consumers if the manufacturer has brand loyalty or if a high percentage of sales are made by manufacturer-owned outlets. ${ }^{204}$ Among the anticompetitive effects of a private label, especially when it becomes dominant, are that it may increase the search costs of consumers, affect consumer choice and variety if all but the leading national brand is excluded, and increase retail prices. ${ }^{205} \operatorname{Lianos}^{206}$ and Gilo ${ }^{207}$ have noted that the Commission subjects dual distribution to a more lenient regime, ${ }^{208}$ ignoring the horizontal dimension of the source of the restraint. Vertical restraints, except for exclusive distribution, may bring more anticompetitive effects than where the supplier does not have its own distribution stores. ${ }^{209}$

\footnotetext{
${ }_{197}$ Conwood Co v United State Tobacco Co, 290 F 3d 768 (6th Circuit 2002); FTC v HJ Heinz Co, 116 F Supp 2d 190 (DDC 200), rev'd, 246 F 3d 708 (DC Cir 2001) cited in Wright (n 185) 179.

${ }^{198}$ GVR (n 16) paras 203-208.

${ }^{199}$ David Gilo, 'Private Labels, Dual Distribution, and Vertical Restraints - an Analysis of the Competitive Effects', in Ezrachi and Bernitz (eds) (n 62) 140.

${ }^{200}$ Lianos (n 62) 172-174.

201 ibid 172.

202 ibid 174.

${ }^{203}$ GVR (n 16) paras 116, 210.

${ }^{204}$ Lianos (n 62) 174.

205 ibid 176.

206 ibid 185.

${ }^{207}$ Gilo (n 199) 143-147.

${ }^{208}$ GVR (n 16) para 28.

${ }^{209}$ Gilo (n 199) 160.
} 


\section{Vertical Restraints Facilitating Horizontal Collusion: 'Stretching' Agreements in a Comparative Approach}

On the other hand, vertical restraints in the presence of a private label are excluded from the VBEs, but they should not always be treated as horizontal, especially when they do not limit the use of private labels. ${ }^{210}$ The above-mentioned incongruence persists in the new VBEs. It may be a case of withdrawing the VBEs, in the case of vertical restraints in nonreciprocated dual distribution while using article 101(3) for efficiency-enhancing restraints in private label settings.

\section{E. LEGAL TOOLS AND ENFORCEMENT}

The consequences of unlawfulness of vertical restraints facilitating tacit coordination are varied and relate to the remedies to be adopted. On the enforcement side, Posner strongly advocates for financial penalties, injunctions, and damage claims in the context of tacit coordination since the mere threat "would cause firms in oligopolistic markets to think twice before turning away business on the basis of how competitors might react to the price cut necessary to get that (profitable) business'.211

In a vertical context, it seems that where there is an illegal agreement, the perpetrator, that is the coercing/inducing party, should be always held liable. As to the other party, Turner claims that 'stiffening the back of those whom the principal culprit seeks to coerce' may help to prevent violations. ${ }^{212}$ Nonetheless, the two situations should differ according to whether the party is coerced or induced. The GVR include among the relevant factors in the assessment when enforcing article 101(1) on vertical agreements the analysis of whether the restriction was 'imposed' or 'agreed'. ${ }^{213}$ In my judgment, contrary to Turner's view, ${ }^{214}$ only the coerced parties should not be held liable or responsible. On the other hand, if parties are induced, that is by means of sharing the monopolistic profits or receiving side payments, they deserve punishment, should be held liable, and should pay fines proportionate to the probable gains. In mixed situations, eg MFC clauses where the dealer itself can demand the clauses, the party benefiting from softer competition should be held responsible only if it was active in the suggestion.

In addition, settlements and adjustments are instruments that generally comprise the abstention to adopt FPs: in our context, vertical restraints with collusive effects. They also may include early payment of discounted fines. The OFT entered into settlements in the

\footnotetext{
210 ibid 143-147.

${ }^{211}$ Posner (n 2) 99.

212 Turner (n 29) 702.

${ }^{213}$ GVR (n 16) para 121.

${ }^{214}$ See also Lianos (n 67) 1074.
} 
tobacco ${ }^{215}$ and dairy cases. ${ }^{216}$ In the first, large supermarket and dairy processors colluded to increase retail prices by means of sharing commercially sensitive information. In the second, there was indirect exchange of proposed future retail prices between competitors and linking of the retail price of a manufacturer's brand to the retail price of the competing brand of another manufacturer.

Moreover, market investigations, such as those of the former UK Competition Commission (CC) under the Enterprise Act 2002, were especially useful to deal with structural problems facilitated by conducts. As Whish argues, despite its 'time-consuming, expensive and intrusive' nature, market investigations act as a 'safety net' when the Competition Act 1998 cannot work. ${ }^{217}$ They can be effective in pointing out problems and remedies; ${ }^{218}$ for example, in the $\mathrm{CC}$ report on groceries, there was concern about the presence of conditions of tacit coordination and the degree of interaction among suppliers, due to the large amount of information passed among them, some regarding the future plans in the context of CM. ${ }^{219}$

It is recognised that there are alternative ways of dealing with the complex oligopoly problem. ${ }^{220}$ Merger control seems to be an effective ex ante option. ${ }^{221}$ However, concerning the enforcement of article 102 to fight tacit coordination, Mezzanote and Monti comment that the high risk of error makes it inappropriate. ${ }^{222}$ Stroux argues that in terms of evidence requirements it does not add anything to art. $101 .^{223}$

In the US context, it is worth mentioning briefly Section 5 of the FTC Act. As reported by Gavil and others, in the 1980s it was used by FTC to fill the gap in the Sherman Act to reach conducts that violate the 'spirit; of antitrust statutes or further public values ${ }^{224}$ but, as shown, the failure of DuPont has chilled the effort. ${ }^{225}$ Peritz argues that the proof of

\footnotetext{
${ }^{215}$ Office of Fair Trading, 'OFT reaches early resolution agreements in tobacco case' (Press Release 82/08, 11 July 2008); Office of Fair Trading, 'OFT imposes $£ 225 \mathrm{~m}$ fine against certain tobacco manufacturers and retailers over retail pricing practices’ (Press Release 39/10 16 April 2010).

${ }^{216}$ Office of Fair Trading 'OFT welcomes early resolution agreements and agrees over $£ 116 \mathrm{~m}$ penalties' (Press Release 170/07 7 December 2007); Office of Fair Trading, 'Lactalis McLelland agrees early resolution in dairy retail price initiatives investigation' (Press Release 22/08 15 February 2008).

${ }^{217}$ Whish (n 1) 569.

218 See Monti (n 128) 343, 344.

${ }^{219}$ Competition Commission, 'The supply of groceries in the UK: market investigation' (Report 30 April 2008) 147-155.

${ }^{220}$ See Whish (n 1) 550-552.

${ }^{221}$ See Stroux (n 19) chs 8-9.

${ }^{222}$ Félix E Mezzanotte, 'Using Abuse of Collective Dominance in Article 102 TFEU to Fight Tacit Collusion: the Problem of Proof and Inferential Error', (2010) March 33(1) World Competition 90; Monti (n 128) 336-338.

${ }^{223}$ Stroux (n 19) 170.

${ }^{224}$ Gavil, Kovacic and Baker (n 11) 344.

${ }^{225}$ Vita (n 8) comments that DuPont was not an economically robust case.
} 
agreement is not the only way to trigger a Section 5 violation; it is equally established with evidence of anticompetitive intent or lack of an independent business reason in the individual conduct. ${ }^{226}$ Thus, he supports a rehabilitation of Section 5 since, according to FTC congressional mandate, its scope is broader than Section 1 and 2 and it should focus on practices at their incipiency. ${ }^{227}$

Gavil and others seem to argue that intent or lack of independent reason would work as a positive factor in the conscious parallelism, as circumstantial evidence of concerted action. ${ }^{228}$ This may lead to a different view, expressed by Page that, after Twombly, there is no substantive gap between Section 5 and Section 1 but a procedural gap. ${ }^{229}$ This can be passed by means of application to the FTC by private parties, who lack detailed information that makes conspiracy plausible. They may present evidence to FTC, and after its collection of information, they could proceed under Section $1 .{ }^{230}$ I would side with Peritz since Section 5 is substantially different from Section 1 and the requirement of agreement is not at all present therein. In economically robust cases, Section 5 would be especially effective when a vertical restraint, such as MFC or exclusive dealing, is adopted by only some of the firms. ${ }^{231}$

\section{F. CONCLUSION}

Networks of vertical restraints blur the differences between vertical and horizontal agreements; therefore, both options of attack are available for enforcers in the EU and the US context. If the analysed vertical restraints are adopted in parallel by agreement, they should be deemed illegal as long as they restrict competition, producing collusive consequences. In the absence of explicit coordination to adopt the practice, I suggest first looking for a stretched concept of horizontal agreement or a broadly interpreted concept of concerted practice, including unilateral 'communication' that intentionally reduces uncertainty. Even when the analysed practices are adopted individually and not by all firms, they can represent a commitment to focal points, observable by market players, thus amounting to communication of intent. If that is not possible, I then propose that an analysis of market power, incentives, coercion and induction should guide the finding of an illegal vertical agreement and ground the analysis of the consequences. The agreement/concerted practice

\footnotetext{
${ }^{226}$ Peritz (n 32) 4.

227 ibid.

${ }^{228}$ Gavil, Kovacic and Baker (n 11) 346.

${ }^{229}$ William H Page, 'The FTC's Procedural Advantage in Discovering Concerted Action', University of Florida Levin College of Law Research Paper No 2009-10 5.

230 ibid.

${ }^{231}$ Baker (n 14) 530.
} 
path is an appropriate, feasible and coherent way to deal with vertical restraints facilitating horizontal tacit coordination, but also does not exclude alternative effective enforcement mechanisms. 